\title{
THE WAVE OVERTOPPING SIMULATOR
}

Jentsje W. van der Meer ${ }^{1}$, Patrizia Bernardini ${ }^{2}$, Wout Snijders ${ }^{3}$ and Eric Regeling ${ }^{4}$,

\begin{abstract}
The wave overtopping simulator is a device which will be able to simulate overtopping waves at the crest and at the inner slope of a dike, levee or embankment in situ. The idea is that real waves are not required to simulate only the overtopping part of waves and that enough information on overtopping waves has been developed by years of research, to describe in detail the hydraulic behaviour at the crest of a dike. The simulator is a box which will be filled with a constant discharge of water and it will release this water at specific times, creating an overtopping wave. The device will be used for the first time in the European ComCoast and Dutch SBW project. This paper describes the design and, after construction, the calibration of the wave overtopping simulator.
\end{abstract}

\section{INTRODUCTION}

The process of wave overtopping on a dike, levee, seawall or embankment is well understood, as a huge amount of research has been devoted to this subject. More recently, also the hydraulic properties of overtopping waves on the crest and inner slope of a dike or embankment were established, such as velocities and flow depths of overtopping waves, see Schüttrumpf and Van Gent (2003). The overall conclusion is that the hydraulic part of wave overtopping on a dike or embankment is well known.

But what about the effect of wave overtopping? How strong are the crest and inner slope of a dike, a levee or embankment during overtopping? Erosion and sliding down of parts or the whole inner slope has often been the leading failure mechanism to dike breach, certainly during the severe floods in 1953 in The Netherlands and UK, in 1962 in north of Germany and recently with hurricane Katrina in the US. The problem is that the strength of a dike cannot be scaled down (grass, clay) to small scale testing and that large scale testing or testing in situ is the only solution.

In order to establish the resistance or strength of a dike for wave overtopping, it is actually sufficient to imitate only the pattern of the overtopping part of the process. Real waves and a large scale facility as the Delta flume or GWK are not required.

\section{IDEA BEHIND DEVELOPMENT OF WAVE OVERTOPPING SIMULATOR}

The idea is that for a given situation:

- everything on wave breaking on slopes and generating overtopping discharges is known;

\footnotetext{
${ }^{1}$ Infram, POBox 16, 8316 ZG Marknesse, The Netherlands, jentsje.vandermeer@infram.nl

${ }^{2}$ Rijkswaterstaat, RWS DWW, PO Box 5044, 2600 AA Delft, The Netherlands,

${ }^{3}$ Rijkswaterstaat, RWS DWW, PO Box 5044, 2600 AA Delft, The Netherlands,

${ }^{4}$ Rijkswaterstaat, RWS IJG, PO Box 600, 8200 AP, Lelystad, The Netherlands
} 
- everything on the pattern of overtopping waves is known as volumes, distributions, velocities and flow depths of overtopping water on the crest;

- only overtopping waves will be simulated, real waves are not required;

- tests will be performed in situ on each dike or levee to be tested, which is much cheaper than testing in a large wave flume.

\section{Present knowledge on strength of dikes by wave overtopping}

Steep inner slopes may fail by a deep slip circle, often observed at failed dikes in the past. This is the reason why more recent dike designs have a gentle inner slope in the order of $1: 3$, stable enough to withstand a deep slip. What could happen for these more gentle inner slopes during wave overtopping?

- local erosion of the grass cover

- development of gulleys and holes in the grass cover

- $\quad$ shallow slip underneath the grass cover or sod (0.2-0.3 m)

- shallow slip underneath the protecting clay layer (0.5-1.0 m)

- development well heads (no failure)

There are only a few guidelines on strength of inner slopes of dikes, levees or embankments and all of them are developed for overflow of water and not wave overtopping. CIRIA report 116 (Hewlett et al. 1987) has been reworked to wave overtopping in The Netherlands, but without validation.

Tests in the Delta flume (Smith 1994) on a 1:2.5 inner slope with grass on good clay showed no damage at all after many hours of testing, up to a wave overtopping discharge of $25 \mathrm{l} / \mathrm{s}$ per $\mathrm{m}$. These tests were performed in summer, with the grass in good condition. In reality most storms in The Netherlands are in winter, with also the grass in a less good, not growing, condition. Tests were also perfomed in the GWK, the large wave flume in Hannover, Germany (Möller et al. 2002). These tests were performed on fresh installed clay without any cover and showed gulleys and big holes at the inner slope within half an hour and only with a 2 l/s per m of wave overtopping. Reality will probably lay between the Delta flume and GWK results.

Recently two Master studies became available on possible failure mechanisms caused by wave overtopping. Young (2005) describes a mechanism of a shallow slip, including the strength of the grass roots. Van den Bos (2006) describes the development of a scour hole at weak spots on the inner slope. Non of these theoretical models could be validated. The wave overtopping simulator can be used for such a validation.

\section{Objective of wave overtopping simulator}

The objective of the wave overtopping simulator is to simulate overtopping waves, as forecasted for a particular storm, in situ at the dike or levee crest and to study the behaviour of the stability of crest and inner side. Eventually, this will lead to a better and validated description of the failure mechanism "stability inner side of dike by wave overtopping". 


\section{KNOWLEDGE ON WAVE OVERTOPPING AT THE CREST OF A DIKE}

Wave overtopping is often described by a mean overtopping discharge q. It is given in $\mathrm{m}^{3} / \mathrm{s}$ per $\mathrm{m}$ or in litres/s per $\mathrm{m}$ width and it is simply the total volume of water which overtopped the dike in a certain period, divided by the total duration. The actual behaviour is very dynamic, in contrast to a mean discharge. Now and then large waves reach the crest and in a few seconds large volumes of water flow over the crest. This whole hydraulic process has been subject for research during many years and gained results are able to describe in detail how a wave simulator should perform.

Equations for the mean wave overtopping discharge have been given in TAW (2002), in the EA Manual (Besley, 1999) and in EAK (2002). Wave overtopping has also been the subject in the European Research Project CLASH, leading to an artificial neural network for prediction of the mean overtopping discharge, see Pozueta et al., 2004. The wave run-up and overtopping formulae in TAW (2002) have been used in this paper, but will not be repeated here.

The 2\%-wave run-up level from TAW (2002) can be used to calculate the percentage of waves overtopping a particular crest freeboard, assuming a Rayleigh distribution for the run-up levels. Each overtopping wave gives a certain volume, $\mathrm{V}$, overtopping the crest. The distribution of these overtopping volumes can be described by a Weibull distribution and has a shape factor of 0.75 and a scale factor a, which depends on the mean wave overtopping discharge and the probability of an wave overtopping, $\mathrm{P}_{\mathrm{ov}}$, see TAW (2002). The probability distribution function is given by:

$$
P_{V}=P(\underline{V} \geq V)=\exp \left(-\left(\frac{V}{a}\right)^{0.75}\right) \text { with a }=0.84 \mathrm{~T}_{\mathrm{m}} \mathrm{q} / \mathrm{P}_{\mathrm{ov}}
$$

The overtopping simulator should match the probability density function in equation (1). Recent information is available on velocities and flow depths at the crest of a dike. Schüttrumpf and Van Gent (2003), give formulae for the maximum velocity, $\mathrm{u}_{\mathrm{A}, 2 \%}$, and maximum flow depth, $\mathrm{h}_{\mathrm{A}, 2 \%}$, at the transition from outer slope to crest of a dike, exceeded by $2 \%$ of the incident waves.

$$
\begin{aligned}
\frac{u_{A, 2 \%}}{\sqrt{g H_{s}}} & =c_{A, u}^{*} \sqrt{\left(\frac{R_{u 2 \%}-R_{C}}{H_{s}}\right)} \\
\frac{h_{A, 2 \%}}{H_{s}} & =c_{A, h}^{*}\left(\frac{R_{u 2 \%}-R_{C}}{H_{s}}\right)
\end{aligned}
$$

where $\mathrm{R}_{\mathrm{u} 2 \%}=2 \%$-run-up level and $\mathrm{R}_{\mathrm{c}}=$ crest freeboard

The empirical coefficients $\mathrm{C}_{\mathrm{A}, \mathrm{h}}$ and $\mathrm{C}_{\mathrm{A}, \mathrm{u}}{ }$ were established in two separate investigations: Schüttrumpf (2002) and Van Gent (2002). The coefficients found were $\mathrm{c}_{\mathrm{A}, \mathrm{h}}^{*}=0.33$ and 0.15 and $\mathrm{c}_{\mathrm{A}, \mathrm{u}}^{*}=1.37$ and 1.30 , respectively. The 
coefficients for the maximum velocity are similar, but for the flow depth a factor more than 2 is present. For the time being both values for this coefficient will be used. For the maximum velocity an average value of $\mathrm{c}_{\mathrm{A}, \mathrm{u}}=1.33$ will be used.

Above equations are only valid for $2 \%$-values. It is possible to find maximum flow depths and velocities for each percentage, and therefore also for each overtopping volume, if the Rayleigh distribution is assumed for wave run-up. In doing so, maximum velocities and flow depths can be calculated for each overtopping volume occurring during a storm with a certain mean overtopping discharge.

Figure 1 shows the maximum velocities for overtopping discharges of $1 ; 10$ and $30 \mathrm{l} / \mathrm{s}$ per $\mathrm{m}$ at the outer crest line. All three mean overtopping discharges give similar velocities for the same volumes per wave overtopping. Also from theoretical reasoning one would expect this, as the same overtopping volume itself is more or less independent from the mean overtopping discharge. An overtopping event with $1000 \mathrm{l} / \mathrm{m}$ in a $1 \mathrm{l} / \mathrm{s}$ per $\mathrm{m}$ discharge should behave similar as a $1000 \mathrm{l} / \mathrm{m}$ event in a $30 \mathrm{l} / \mathrm{s}$ per $\mathrm{m}$ discharge. The difference is of course that the larger discharge will have more of these events, but the event itself should not be too different, provided that the wave periods are more or less similar.

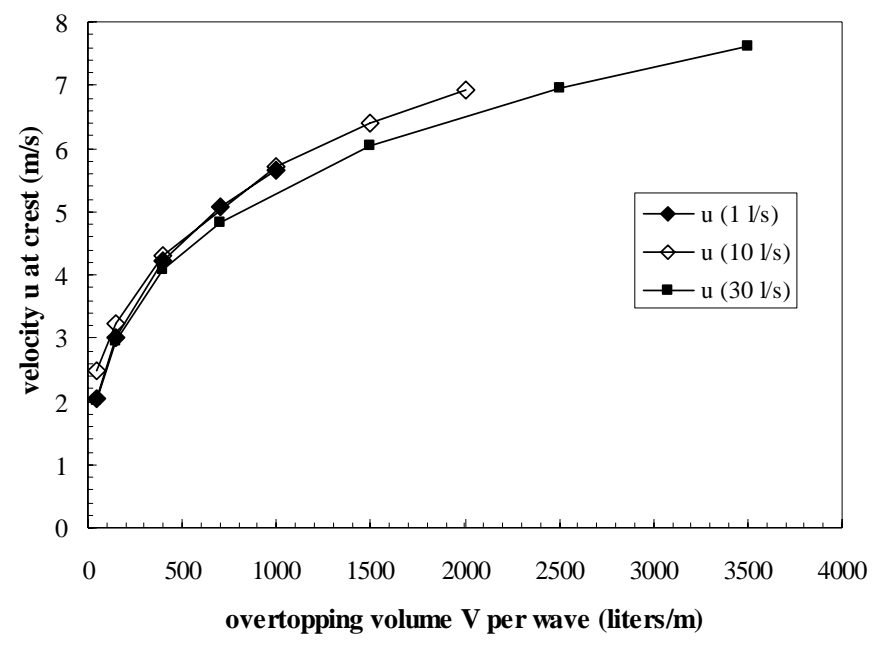

Figure 1. Maximum velocities at the outer crest line as a function of the overtopping volume per wave; $H_{s}=2 \mathrm{~m}, T_{p}=5.7 \mathrm{~s}, \tan \alpha=0.25$

Maximum velocities are about 2-2.5 m/s for small volumes of $50 \mathrm{l} / \mathrm{m}$ and they increase to velocities of about $5.5 \mathrm{~m} / \mathrm{s}$ for $1000 \mathrm{l} / \mathrm{m}$ and up to a maximum of 7-7.5 $\mathrm{m} / \mathrm{s}$ for an overtopping volume of $3500 \mathrm{l} / \mathrm{m}$. Figure 2 gives the flow depth at the outer crest line, both for Schüttrumpf (2002) and Van Gent (2002). The S and V in the Figure give both authors. As mentioned earlier, the differences are more than a factor 2, indicating somewhere an error in measurement or analysis. 


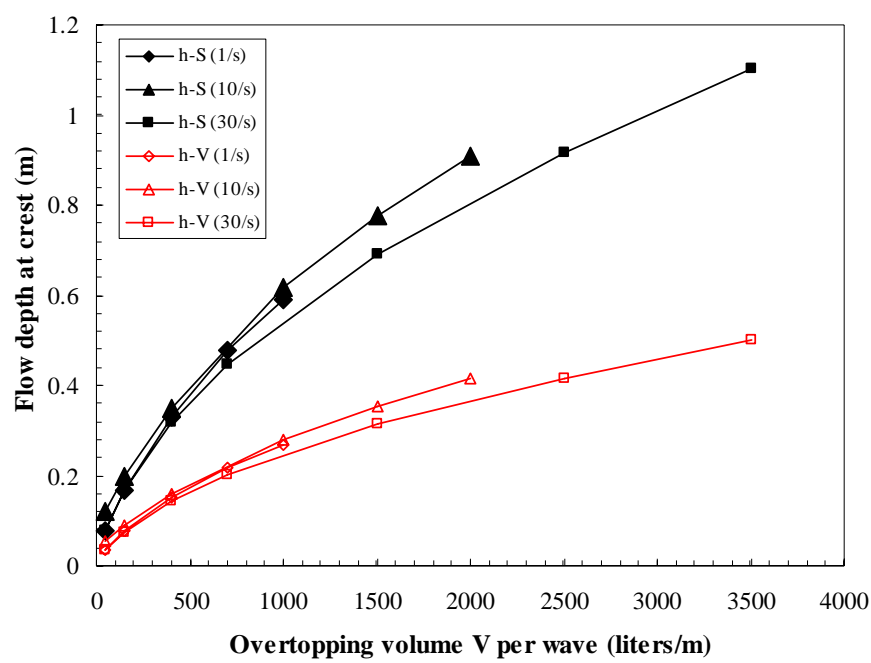

Figure 2. Maximum flow depths at outer crest line according to Schüttrumpf (2002) and Van Gent (2002), and applied for $H_{s}=2 \mathrm{~m}, \mathrm{~T}_{\mathrm{p}}=5.7 \mathrm{~s}, \tan \alpha=0.25$ and various overtopping discharges.

\section{Typical storm with overtopping parameters}

The wave boundary conditions (wave height, period and direction, water level) in front of the dike and the geometry of the dike determine whether there will be wave overtopping and how much. Overall, wave heights around $2 \mathrm{~m}$ are often found as conditions for the safety assessments in The Netherlands. A wave steepness of $\mathrm{s}_{\mathrm{op}}=0.04$, using the peak period, is found in the Waddensea. Of course larger and lower wave heights than $2 \mathrm{~m}$ are found, but for testing with the overtopping simulator a wave height of $2 \mathrm{~m}$ is accurate enough.

In summary, analysing wave boundary conditions along the Dutch coasts, as used for the 5-yearly safety assessment, gives the following mean values which will be used to design the wave overtopping simulator.

- Wave height: $\mathrm{H}_{\mathrm{s}}=2.0 \mathrm{~m}$

- Peak period $\mathrm{T}_{\mathrm{p}}=5.7 \mathrm{~s}$ (wave steepness $\mathrm{s}_{\mathrm{op}}=0.04$ )

- $\quad$ Mean period $\mathrm{T}_{\mathrm{m}}=4.7 \mathrm{~s}\left(\mathrm{~T}_{\mathrm{p}}=1.2 \mathrm{~T}_{\mathrm{m}}\right)$

The seaward slope of the dike is taken at 1:4. For further calculations a storm duration of 6 hours is assumed. With these values and the wave conditions given above, the wave overtopping parameters can be calculated for a given crest freeboard. Table 1 gives the parameters for mean overtopping discharges of $0.1 ; 1$ and $10 \mathrm{l} / \mathrm{s}$ per $\mathrm{m}$. With above chosen wave boundary conditions the $2 \%$-run-up is $4.0 \mathrm{~m}$ above still water level. If the crest level is equal to this $2 \%$-run-up level, the overtopping discharge becomes $0.74 \mathrm{l} / \mathrm{s}$ per $\mathrm{m}$. This is certainly more than the 
lowest limit of $0.1 \mathrm{l} / \mathrm{s}$ per $\mathrm{m}$, but still below the value of $1 \mathrm{l} / \mathrm{s}$ per $\mathrm{m}$. As only $2 \%$ of the waves reach the crest, only 93 waves in a period of 6 hours will overtop the crest. This means in average 15 waves per hour or an overtopping event every 4 minutes.

The main difference in Table 1 is the number of overtopping waves. With 0.1 l/s per m only 9 waves will overtop in 6 hours (one every 40 minutes). For 10 l/s per $\mathrm{m}$ this is almost 1000 (in average every $25 \mathrm{~s}$ an overtopping event).

\begin{tabular}{|c|c|c|c|}
\hline & $\mathrm{q}=0.1 \mathrm{l} / \mathrm{s}$ per $\mathrm{m}$ & $q=1 \mathrm{l} / \mathrm{s}$ per $\mathrm{m}$ & $\mathrm{q}=10 \mathrm{l} / \mathrm{s}$ per $\mathrm{m}$ \\
\hline Percentage overtopping & 0.192 & 2.744 & 18.89 \\
\hline Number of waves in 6 hours & 4600 & 4600 & 4600 \\
\hline Number of overtopping waves & 9 & 126 & 868 \\
\hline Maximum overtopping volume & $580 \mathrm{l} / \mathrm{m}$ & $1177 \mathrm{I} / \mathrm{m}$ & $2675 \mathrm{I} / \mathrm{m}$ \\
\hline
\end{tabular}

\section{TARGETS FOR THE WAVE OVERTOPPING SIMULATOR}

Table 1 only gives the maximum overtopping volume in a storm. But overtopping volumes in overtopping waves follow the distribution described by equation (1). It is this distribution which should be generated by the simulator and preferably schematized to a fixed number of overtopping volumes as it will be difficult, and also not required, to generate exactly each volume individually. An example is given in Figure 3 for 1 l/s per m, during 6 hours and for a wave height of $2 \mathrm{~m}$.

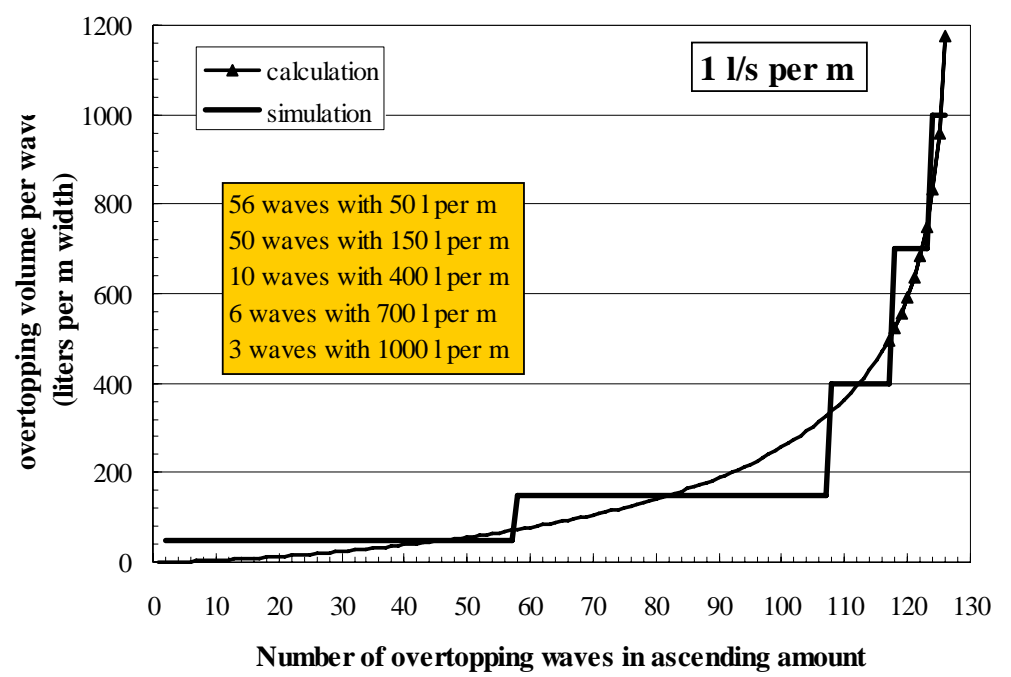

Figure 3. Calculated distribution of overtopping volumes and proposal for simulation. Mean discharge $q=1 \mathrm{l} / \mathrm{s}$ per $\mathrm{m}$ 
Around 120 waves will overtop in these 6 hours, which means around 20 per hour. The overtopping volumes could be simulated as follows:

- 56 waves with $50 \mathrm{l}$ per m

- 40 waves with $150 \mathrm{l}$ per m

- 10 waves with $400 \mathrm{l}$ per $\mathrm{m}$

- 6 waves with $700 \mathrm{l}$ per m

- 3 waves with $1000 \mathrm{l}$ per m

Of course the volumes should be generated in arbitrary order. Similar graphs as Figure 3 can be made for each prescribed overtopping condition. Besides maximum flow velocities and flow depths (equations 2 and 3), there is also variation in time. Till now published research has not been focussed on this item. A sea state with a peak period of 5 seconds will give another time record of overtopping waves than a long period of $10 \mathrm{~s}$, both with the same wave height. The wave period has influence on the time record of overtopping and this might well be the reason for the small differences in flow velocity in Figure 1.
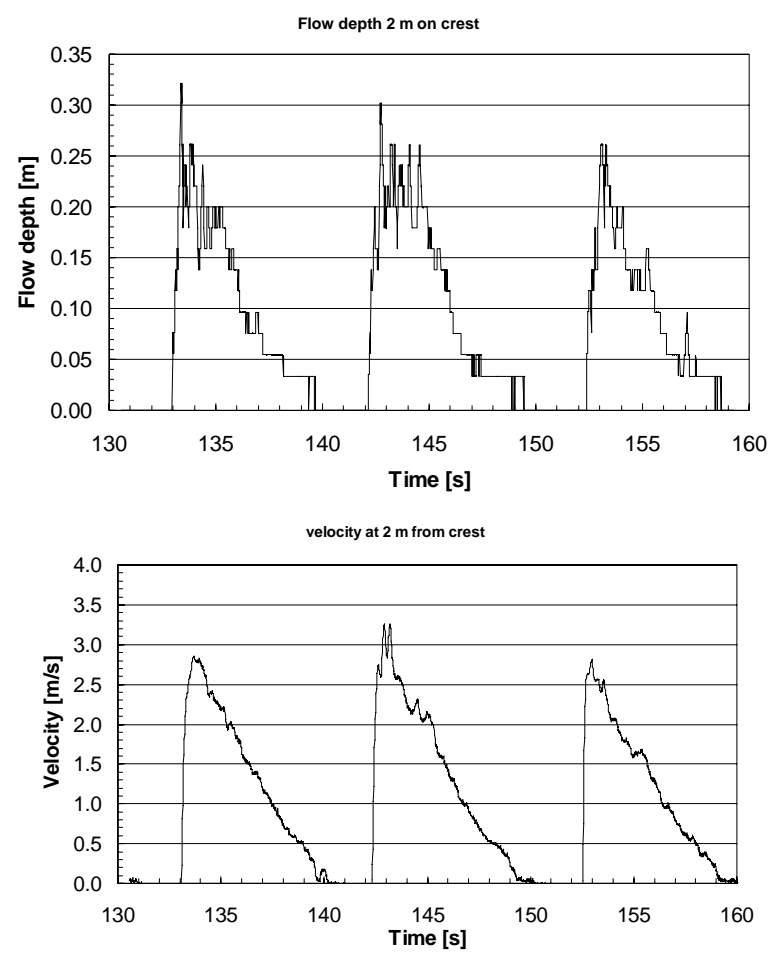

Figure 4. Time records of flow depth and flow velocity at the crest. Tests by Schüttrumpf (2002). Regular waves. Test 31050010. $\mathrm{H}=0.87 \mathrm{~m}, \mathrm{~T}=9.5 \mathrm{~s}$. Measured overtopping discharge was $60.0 \mathrm{l} / \mathrm{s}$ per $\mathrm{m}$ 
The prototype of the wave overtopping simulator must actually simulate the expected time record of flow velocity and flow depth and not only the maximum values. Figure 4 shows a time record of flow depth and velocity with regular waves, taken from the research of Schüttrumpf (2002). The shape of the overtopping record is more or less triangular with a steep front. For design and calibration of the wave overtopping simulator the total time, $t_{1}$, that water flows over the crest, is needed. For the time being it is assumed that maximum flow times of about $0.5-0.8 \mathrm{~T}_{\mathrm{p}}$ simulate larger overtopping volumes (around 3-5 s) and $0.3-0.5 \mathrm{~T}_{\mathrm{p}}$ give smaller overtopping volumes $(2-3 \mathrm{~s})$.

Volumes to be simulated by the wave overtopping simulator will vary between about $50 \mathrm{l}$ per $\mathrm{m}$ and maximum $3500 \mathrm{l}$ per m. Based on Figure 1 with the predicted overtopping flow velocities the following targets were set for the simulator to be met, where model uncertainty of the prediction has been taken into account, see Table 2 .

\begin{tabular}{|c|c|c|c|}
\hline \multicolumn{4}{|c|}{ Table 2. Targets set for calibration of the wave overtopping simulator } \\
\hline Overtopping volume $(\mathrm{l} / \mathrm{m})$ & flow velocity $(\mathrm{m} / \mathrm{s})$ & range $(\mathrm{m} / \mathrm{s})$ & ${\text { flow time } \mathrm{t}_{1}(\mathrm{~s})}$ \\
\hline 50 & $2.0-2.5$ & $1.5-3.0$ & $1.5-2.5$ \\
\hline 150 & $2.9-3.2$ & $2.5-3.5$ & $1.5-2.5$ \\
\hline 400 & $4.1-4.3$ & $3.5-5.0$ & $2.0-3.0$ \\
\hline 700 & $4.8-5.1$ & $4.2-5.7$ & $2.5-3.5$ \\
\hline 1000 & 5.7 & $5.0-6.5$ & $3.0-4.0$ \\
\hline 1500 & 6.2 & $5.5-7.0$ & $3.0-4.0$ \\
\hline 2500 & 6.9 & $6.0-8.0$ & $3.5-5.0$ \\
\hline 3500 & 7.6 & $6.5-8.5$ & $3.5-5.0$ \\
\hline
\end{tabular}

\section{DESIGN OF THE WAVE OVERTOPPING SIMULATOR}

Overtopping waves are random in time and give different overtopping volumes/m per overtopping event. Given such an overtopping volume, the water flows with a certain velocity over the crest and inner slope of the dike, with a certain flow depth and in a certain time, see Table 2. The overtopping simulator should simulate the right velocity and flow depth in time at the crest of the dike, for a given overtopping volume. Overtopping volumes will vary between $50 \mathrm{l} / \mathrm{m}$ and $3500 \mathrm{l} / \mathrm{m}$ (the maximum for $30 \mathrm{l} / \mathrm{s}$ per $\mathrm{m}$ ). Roughly the velocities will vary between $2 \mathrm{~m} / \mathrm{s}$ up to around $8 \mathrm{~m} / \mathrm{s}$.

The following aspects have been considered for the technical design of the device:

- $\quad$ maximum volume: $3.5 \mathrm{~m}^{3} / \mathrm{m}$ (4 m wide, in total $14 \mathrm{~m}^{3}$ );

- shape of the box: as high and slender as possible, in order to reach the large velocities for large volumes;

- $\quad$ opening of the valve: maximum $0.50 \mathrm{~m}$, to be adjusted during calibration.

- $\quad$ possibility to place the device at different heights with respect to the crest: legs of 2 m length;

- $\quad$ shape of transition slope; to be adjusted during calibration. 
The idea was to make a mobile box or carrier to store water, fill this box continuously with a required discharge $\mathrm{q}$ and empty this box at certain times in such a way that it simulates the overtopping tongue of a wave at the crest and inner slope of a dike. Figure 5 shows the prototype ( $1 \mathrm{~m}$ wide) of the wave overtopping simulator. The box in reality will be $4 \mathrm{~m}$ wide. The boundary condition is a certain mean overtopping discharge $\mathrm{q}$ and this mean discharge is indeed pumped into the box. As soon as the box is filled with a prescribed volume, $\mathrm{V}$, the valve is opened and water released on a transition slope to the front of the crest. The discharge of water will be released in such a way that speed, turbulence and thickness of the outgoing stream will correspond with the water flow that is expected at the crest. The calibration was meant to give the right configuration.

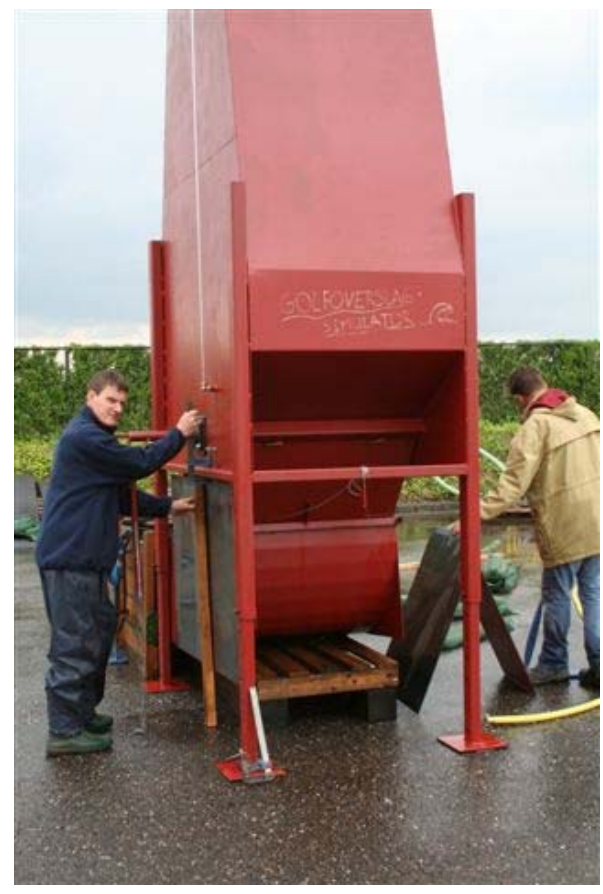

\section{CALIBRATION OF THE WAVE OVERTOPPING SIMULATOR}

The simulator was calibrated at the manufacturer. An empty part of the parking place was used which was situated along a ditch with clean water. The dike crest was simulated by a $2 \mathrm{~m}$ long and $1 \mathrm{~m}$ wide flume with a height of $0.6 \mathrm{~m}$. After these 2 $\mathrm{m}$ the water could flow freely to the sewage system. Two pumps were available, one of $3 \mathrm{l} / \mathrm{s}$ and one of $8 \mathrm{l} / \mathrm{s}$. Both could be used at the same time to fill up the simulator to a required volume.

Figure 6 gives an idea of the release of the maximum volume of 3500 l, Figure 7 gives the front view of a volume of only $150 \mathrm{l}$. Van der Meer (2006) gives a full report of the calibration.

Figure 5. Rear side of the $1 \mathrm{~m}$ wide prototype of the wave overtopping simulator

\section{Measurements and instrumentation}

An electro magnetic velocity meter (EMS) was rented from WL | Delft Hydraulics, together with an acoustic depth meter (LDM). The EMS was placed 2 $\mathrm{cm}$ above the bottom of the flume (or dike crest) and $1.5-2 \mathrm{~m}$ from the end of the transition slope of the simulator. The depth meter was placed about $1.2 \mathrm{~m}$ above the bottom of the flume at the same location. A linear scale was placed at the wall of the flume in order to make visual observations of flow depths. 

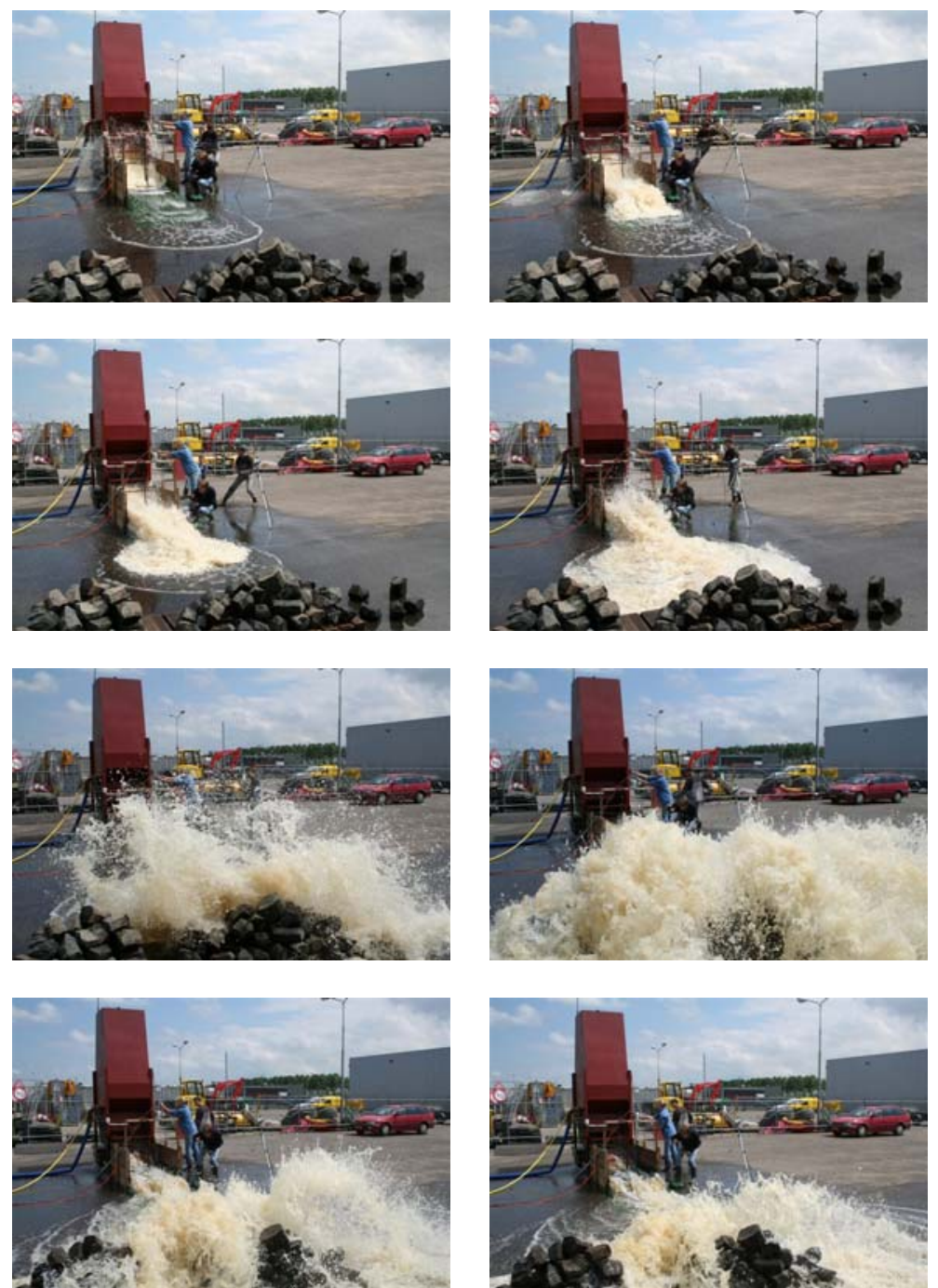

Figure 6. Front view of a test with $3500 \mathrm{I}$; the total event takes about $5 \mathrm{~s}$

Flow simulations were performed and both manually and digitally velocities and flow depths were measured. Tests C1000 had water volumes of $1000 \mathrm{l}$ and the simulations were repeated 6 times. Figure 8 shows the records of velocity and flow depth of tests C1000-1. The actual simulation takes place from about $\mathrm{t}=1 \mathrm{~s}$ to 5 or $6 \mathrm{~s}$. After that flow depths are almost zero and the EMS gives spikes as it is not submerged anymore. The maximum velocity measured is $5.3 \mathrm{~m} / \mathrm{s}$. The maximum flow depth measured is at least $0.2 \mathrm{~m}$ and sometimes more than $0.3 \mathrm{~m}$. 

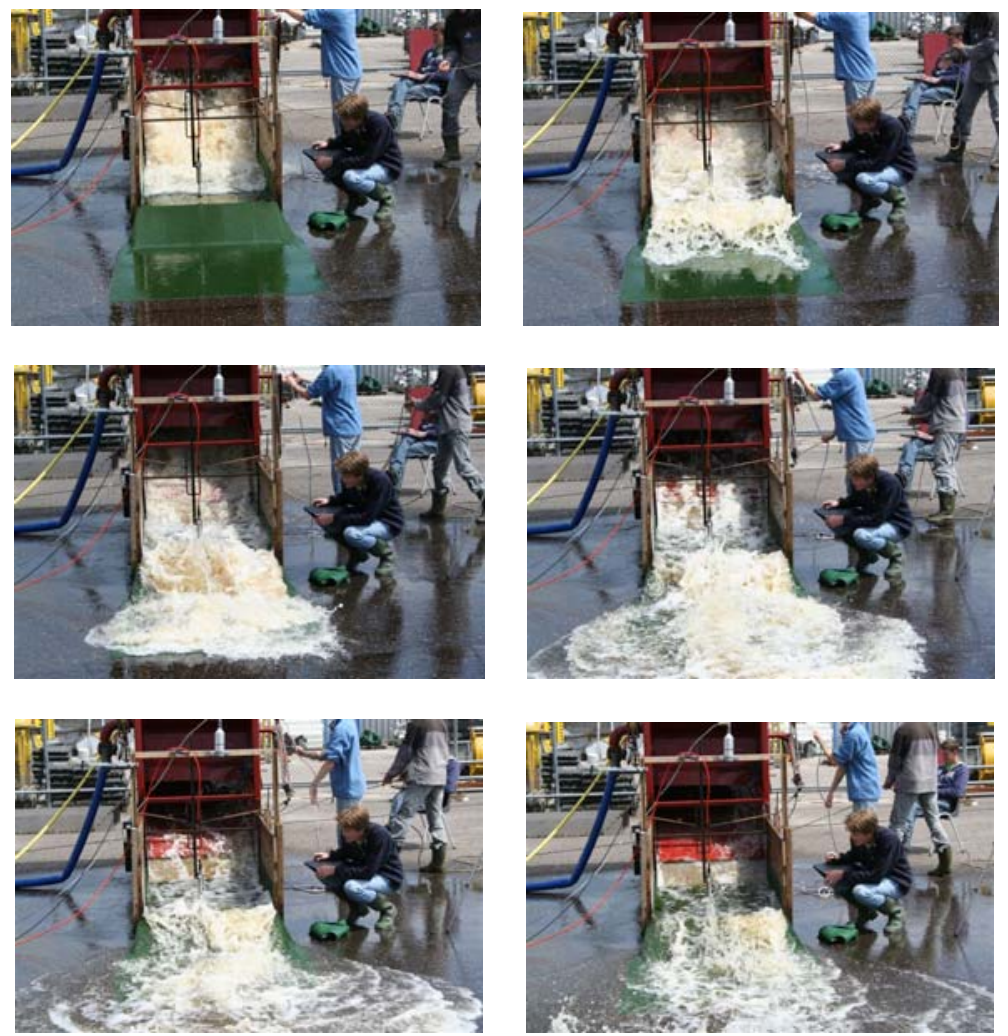

Figure 7. Front view of a test with $150 \mathrm{I}$; the total event takes about 2-3 s

The maximum flow depth was also recorded visually at the side wall of the flume at the location of the flow depth meter. In all tests with $1000 \mathrm{l}$ the maximum flow depth was $0.12-0.13 \mathrm{~m}$. By no means flow depths of 0.2 or $0.3 \mathrm{~m}$ were seen. The flow is highly turbulent with a lot of air entrainment and the surface is not smooth. At the end of the simulation the flow has less air and is less turbulent. It was concluded that the flow depth meter can not measure correctly the flow depth when the flow is so turbulent. Probably the part after $4.5 \mathrm{~s}$ was measured correctly. The relevant parts of the velocity records of tests $\mathrm{C} 1000$ were placed in one graph, starting at $\mathrm{t}=1 \mathrm{~s}$. This graph is shown in Figure 9. The records are quite similar, which means that the flow simulation can be repeated quite well. They also have the triangular shape described in Figure 4.

\section{Analysis of calibration}

The calibration included various set-ups of the transition slope, various heights of the box and trials to improve the speed to open the valve. The final test series $\mathrm{K}$ gave simulations according to the targets set in Table 2 . The final results are given in Table 3 and are compared with the targets. 


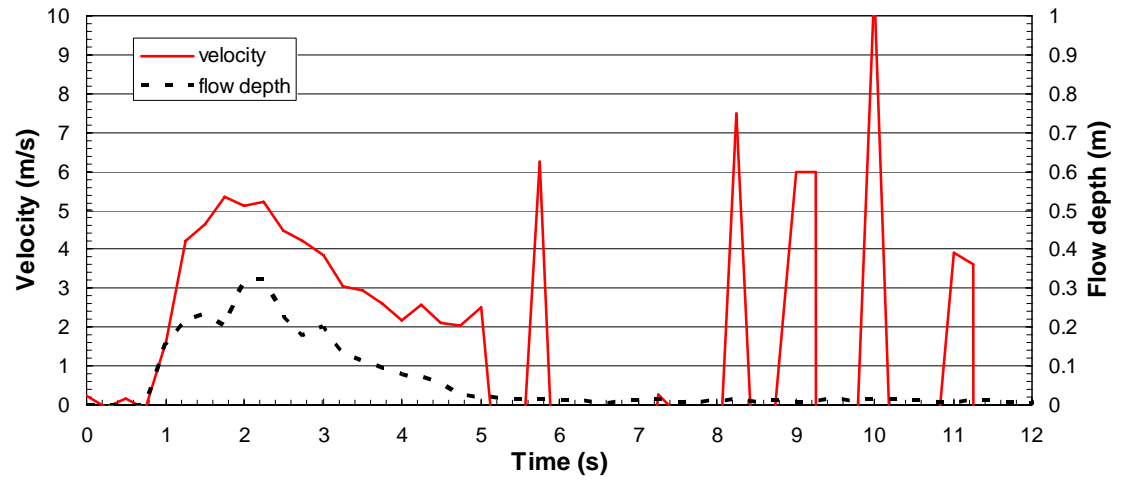

Figure 8. Records for test C1000-1

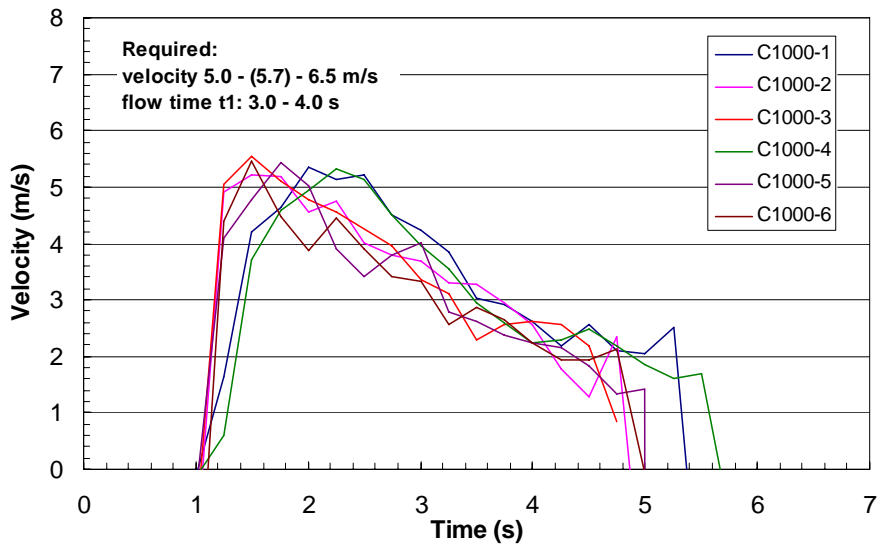

Figure 9. Velocity measurements for $\mathrm{C} 1000(\mathrm{~V}=1 \mathrm{~m} 3)$

Table 3. Final results for calibration series $K$

\begin{tabular}{|c|c|c|c|c|c|c|c|}
\hline$\stackrel{\overrightarrow{\mathscr{N}}}{\stackrel{\varrho}{\varrho}}$ & 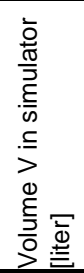 & 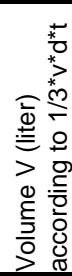 & 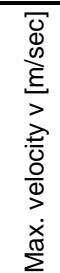 & 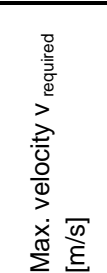 & 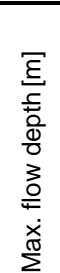 & 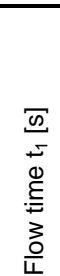 & 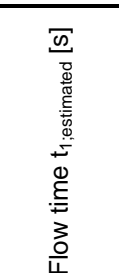 \\
\hline K50 & 50 & 35 & 2.73 & $1.5-3.0$ & 0.04 & 0.94 & $1.5-2.5$ \\
\hline K150 & 150 & 140 & 2.95 & $2.5-3.5$ & 0.10 & 1.48 & $1.5-2.5$ \\
\hline K400 & 400 & 290 & 3.43 & $3.5-5.0$ & 0.13 & 2.05 & $2.0-3.0$ \\
\hline K700 & 700 & 490 & 4.10 & $4.2-5.7$ & 0.15 & 2.38 & $2.5-3.5$ \\
\hline K1000 & 1000 & 790 & 4.62 & $5.0-6.5$ & 0.18 & 2.78 & $3.0-4.0$ \\
\hline K1500 & 1500 & 1100 & 4.84 & $5.5-7.0$ & 0.20 & 3.40 & $3.0-4.0$ \\
\hline K2500 & 2500 & 2370 & 6.47 & $6.0-8.0$ & 0.26 & 4.24 & $3.5-5.0$ \\
\hline K3500 & 3500 & 3760 & 7.07 & $6.5-8.5$ & 0.30 & 5.48 & $3.5-5.0$ \\
\hline
\end{tabular}




\section{CONCLUSIONS}

The simulator is able to simulate overtopping waves in a realistic manner, according to the targets set, which were based on available knowledge of wave overtopping. Knowledge on flow times of individual overtopping waves is not sufficient and analysis of existing measurements (Schüttrumpf and Van Gent, 2003) is recommended.

The calibration gave some points to improve the final set-up of the wave overtopping simulator and these will be taken into account during the construction of the actual simulator of $4 \mathrm{~m}$ wide (November 2006). The instruments to measure velocity and flow depth have to be improved. Actual testing on a sea dike will start March 2007 under the European ComCoast and Dutch SBW project (Strength of and loads on flood defences).

\section{REFERENCES}

Besley, P. 1999. Overtopping of seawalls-design and assessment manual. $R \& D$ Technical Report W178, Environment Agency, Bristol, ISBN 185705069 X

EAK. 2002. Empfehlungen des Arbeitsausschusses Küstenschutzwerke. Die Küste. H. 65. (Guideline in German)

Hewlett, H.W.M, L.A. Boorman and M.E. Bramley, 1987. Design of reinforced grass waterways. CIRIA Report 116, London

Pozueta B., M.R.A. van Gent, H. van den Boogaard and J.R. Medina. 2004. Neural network modelling of wave overtopping at coastal structures. ASCE, Proc. ICCE, Lisbon, pp. 4275-4287.

Möller J.; R. Weißmann, H. Schüttrummpf, J. Grüne, H. Oumeraci, W. Richwien and M. Kudela. 2002: Interaction of wave overtopping and clay properties for seadikes. ASCE, Proc.ICCE, Volume 2, Cardiff, U.K., pp. 2105-2127

Schüttrumph, H. and M.R.A. van Gent. 2003. Wave overtopping at seadikes. ASCE, Proc. Coastal Structures 2003, 431-443.

Smith, G.M.1994. Grasdijken (Dutch). Grass dikes. Delft Hydraulics report H1565, Delft

Schüttrumpf, H., J. Möller and H. Oumeraci. 2002. Overtopping flow parameters on the inner slope of seadikes. ASCE. Proc. ICCE 2002, Cardiff, UK.

TAW. 2002. Wave run-up and wave overtopping at dikes. Technical Report Technical Advisory Committee for Flood Defence in the Netherlands (TAW). Delft. 2002

Van den Bos, W. 2006. Erosiebestendigheid van grasbekleding tijdens golfoverslag (in Dutch - Erosion resistance of grass cover during wave overtopping). MSc-thesis Delft University

Van der Meer, J.W. 2006. Design, construction and calibration of wave overtopping simulator. Infram report $04 i 103$.

Van Gent, M.R.A.. 2002. Wave overtopping events at dikes. ASCE. Proc. ICCE 2002, Cardiff, UK.

Young, M.J., 2005. Wave Overtopping and Grass Cover Layer Failure on the Inner Slope of Dikes. MSc Thesis WSE-CEPD-05.03, UNESCO-IHE. 